\title{
Spiritual and religious identities predict the use of complementary and alternative medicine among US adults*
}

\author{
Christopher G. Ellison, Ph.D., \\ Department of Sociology, The University of Texas at San Antonio \\ Matt Bradshaw, Ph.D., and \\ Department of Sociology and Duke Population Research Institute, Duke University \\ Cheryl A. Roberts, M.A. \\ Carolina Population Center, The University of North Carolina at Chapel Hill
}

\begin{abstract}
Objective-To determine whether spiritual and religious identities predict CAM use above and beyond other known influences such as gender, region of residence, social status, personality, health, and access to conventional medicine.
\end{abstract}

Methods-Analyzing data from the 1995-1996 National Survey of Midlife Development in the United States $(\mathrm{n}=3032)$, this study examines the correlations between four aspects of spirituality / religiousness-i.e., spiritual only, religious only, both spiritual and religious, and neither spiritual nor religious-and six measures of CAM.

Results-Compared with spiritual only persons, the odds of using energy therapies are $86 \%$ lower for spiritual and religious persons, $65 \%$ lower for religious only persons, and 52\% lower for neither spiritual nor religious persons. Compared to spiritual only persons, spiritual and religious individuals are $43 \%$ more likely to use body-mind therapies in general; however, when this category does not contain prayer, meditation, or spiritual healing, they are $44 \%$ less likely. Religious only individuals are disinclined toward CAM use.

Conclusions-After controlling for established predictors including educational attainment, personality, social support, and access to conventional medicine, the present study demonstrates that spirituality and religiousness are associated, in unique ways, with CAM use. Additional research on this topic is clearly warranted.

\section{Keywords}

Health; Behavior; New Age; MIDUS; Adults

\section{Introduction}

Complementary and alternative medicine (CAM) is increasingly embraced in the US as treatment for illness, and as self-care for health and wellness promotion (Barnes et al., 2004;

\footnotetext{
(C) 2011 Elsevier Inc. All rights reserved.

*Direct correspondence to: Matt Bradshaw, 337 Soc/Psych Building, Department of Sociology, Duke University, Durham, NC 27708-0088. Phone: 817-946-1165. Fax: 919-660-5623. drmattbradshaw@yahoo.com.

Publisher's Disclaimer: This is a PDF file of an unedited manuscript that has been accepted for publication. As a service to our customers we are providing this early version of the manuscript. The manuscript will undergo copyediting, typesetting, and review of the resulting proof before it is published in its final citable form. Please note that during the production process errors may be discovered which could affect the content, and all legal disclaimers that apply to the journal pertain.
} 
Kessler et al., 2001; Ni et al., 2002). However, relatively little is known about individual correlates of CAM use (Honda \& Jacobson, 2005; Ni et al., 2002). Such information can promote the development of evidence-based CAM and maximize adherence to therapeutic recommendations. In particular, despite widespread interest in the religion-health connection (Benjamins, 2006; Koenig et al., 2001), the role of religious and spiritual identities in CAM use has been largely ignored (Hildreth \& Elman, 2007; McCurdy et al., 2003).

Understanding how these factors are related to CAM use may assist healthcare providers in tailoring their recommendations for treatment because it will help them determine which individuals might be either open to, or completely averse to, such therapies.

Although America remains a comparatively religious nation and most Americans cultivate spirituality through established (mainly Judeo-Christian) religious institutions (Davis et al., 2008), growing numbers of US adults are pursuing highly individualized forms of spirituality (Fuller, 2001; Roof, 2000). They seek out spiritual insights from varied sources, and combine diverse types of beliefs and rituals into highly personalized modes of spiritual expression, resulting in an increase in the percentage of US adults who self-identify as "spiritual but not religious" (Marler \& Hadaway, 2002; Shahabi et al., 2002; Zhai et al., 2008; Zinnbauer et al., 1999).

These trends may have important implications for CAM use. Although prayer, meditation, and spiritual healing are considered CAM and are well-received within most Christian circles because they are key components of traditional Christian theology and practice (Newport, 1998; O'Mathuna \& Larimore, 2001), many other CAM practices may be denounced because they draw upon Eastern-influenced ideas about spiritual and energy flows, as well as Native American, Theosophist, and New Age belief systems (Fuller, 2001; Levin \& Coreil, 1986). Two areas of CAM have elicited particular condemnation from Christian clergy and religious medical professionals: (1) body-mind therapies, especially hypnosis and guided imagery; and (2) energy therapies, such as healing touch and Reiki massage (O'Mathuna \& Larimore, 2001).

These developments suggest several hypotheses:

1. "Spiritual but not religious" self-identification will be positively associated with use of CAM, especially body-mind therapies and energy therapies.

2. "Spiritual and religious" self-identification will be negatively associated with the use of energy therapies.

3. "Spiritual and religious" self-identification will be negatively associated with the use of body-mind therapies, particularly when this category is defined to exclude prayer, mediation, and spiritual healing.

\section{Methods}

Data come from the baseline National Survey of Midlife Development in the United States (MIDUS), 1995-96 (Brim et al., 2003). Our objective is to examine whether spiritual and religious identities are associated with CAM use above and beyond other known predictors, so our models include controls for other known predictors, as detailed in a previous study in this journal (Honda \& Jacobson, 2005). Following previous research (Marler \& Hadaway, 2002; Shahabi et al., 2002; Zhai et al., 2008), our measures of spiritual/religious (S/R) categories are constructed using two questions: "How religious are you?" and "How spiritual are you?" We categorized persons answering "very" or "somewhat" as "yes" and those answering "only a little" or "not at all" as "no," and then created the "religious and spiritual," "religious only," "spiritual only," and "neither religious nor spiritual categories." 
Missing data are handled using multiple imputation in Stata (Royston, 2005). All variable definitions and descriptive statistics are provided in Table 1.

\section{Results}

Table 2 shows findings from binary logistic regression models that test our hypotheses. They reveal several important results. First, based on models adjusted for many known correlates of CAM use, spiritual only persons are vastly more likely than others to use energy therapies. In model 1 the odds of using energy therapies are $86 \%$ lower ( $\mathrm{OR}=.14$, [. $10, .22])$ for spiritual and religious persons, $65 \%$ lower $(\mathrm{OR}=.35,[.18, .67])$ for religious only persons, and 52\% lower (OR=.48 [.32,.73]) for neither spiritual nor religious persons in comparison with their spiritual only counterparts. According to model 2, the odds of using energy therapies are nearly 6 times greater $(\mathrm{OR}=6.91[4.59,19.40])$ for spiritual only persons, as well as 2.3 times greater $(\mathrm{OR}=3.32[2.23,4.94])$ for neither spiritual nor religious persons and more than twice as great $(\mathrm{OR}=2.38[1.27,4.48])$ for religious only persons, as compared with those who self-identify as spiritual and religious. Taken together, these results are consistent with hypotheses 1 and 2.

Second, when body-mind therapies include prayer, mediation, and spiritual healing, spiritual and religious persons are much more likely than others, including spiritual only persons, to use this form of CAM. For example, in model 2, the odds of using body-mind therapies are $30 \%$ lower $(\mathrm{OR}=.70[.54, .91])$ for spiritual only persons, $74 \%$ lower $(\mathrm{OR}=.26[.17, .38])$ for religious only persons, and $80 \%$ lower $(\mathrm{OR}=.20[.14, .29])$ for neither religious nor spiritual persons than for their spiritual and religious counterparts. Compared to spiritual only persons, those who self-identify as spiritual and religious are still more likely (OR=1.43 $[1.09,1.86])$ to use body-mind therapies in general. However, when the body-mind therapy category is redefined to exclude religious forms of CAM, this pattern shifts significantly. In model 2, the odds of using non-religious body-mind therapies are $79 \%$ higher $(\mathrm{OR}=1.79$, $[1.12,2.83])$ for spiritual only persons than for spiritual and religious persons. Given that including prayer, mediation, and spiritual healing within the definition of CAM greatly increases the prevalence of CAM use (Barnes et al., 2004), and may even bias findings on the relationship between spirituality / religious and CAM use, examining CAM with and without these components, as our study has done, is an important contribution. No other differences among S/R identity groupings are significant. These findings tend to support hypothesis 3 .

We also note in passing two other interesting patterns that emerge from our analyses: (1) Compared to most others, spiritual and religious persons are relatively likely to employ biologically based therapies, such as herbal treatments, high dose vitamins, etc.; and (2) Spiritual only persons are comparatively likely to utilize alternative medical systems, such as acupuncture and homeopathy.

\section{Discussion and Conclusion}

CAM has attracted attention and gained popularity among the medical community, government agencies, and the general public (Kessler et al., 2001; Ni et al., 2002). Many mainstream physicians refer patients to CAM modalities, and individuals use CAM for selfcare to promote health and well-being (Honda \& Jacobson, 2005; Ni et al., 2002). Our study adds to the base of knowledge about individual dispositional factors that are associated with use of CAM. Over and above a host of demographic, physical health, psychiatric, personality, and psychosocial factors-as well as frequency of religious attendancereligious and spiritual identities are independent predictors of certain types of CAM use. 
Persons who self-identify as spiritual and religious are particularly likely to use religious forms of CAM such as prayer, meditation, and spiritual healing, but spiritual only persons are more likely to use other types of body-mind therapies. In addition, spiritual only persons are especially likely, and spiritual and religious persons are especially disinclined, to use energy therapies, such as healing touch and Reiki. Spiritual only persons also exhibit an attraction to alternative medical systems, such as acupuncture, and spiritual and religious persons have an affinity for biologically based therapies. These findings suggest that religious and spiritual identities may influence the market for various CAM modalities, and may condition adherence to treatment regimens if prescribed by medical professionals-i.e., some individuals may be more or less likely to adhere to CAM-based therapies in the first place, and possibly even to benefit more from their use compared with others, based on their spiritual / religious identities. These associations may become even more important as the numbers of spiritual only persons continue to grow in the contemporary US (Fuller, 2001; Zhai et al., 2008).

The study is limited by several factors: (a) use of cross-sectional data, which makes it possible to discuss only associations, and not casual relationships; (b) use of single-item measures to classify respondents into spiritual-religious categories; (c) reliance on a sample of 25-74 year-olds, precluding generalization to younger or older persons; and (d) use of self-report data, with all the potential biases of this mode of data collection. Future research should seek to expand our understanding of spirituality / religiousness and CAM use by examining the role of specific denominational subcultures and theological beliefs. It might be particularly important to examine whether conservative orientations such as those associated with evangelical Protestantism and Mormonism inhibit CAM use, and alternatively, whether the beliefs of various non-Judeo-Christian faiths such as Buddhism and other Eastern religions facilitate the use of CAM. Understanding these influences could help healthcare providers identify individuals who might utilize, and possibly even benefit from, CAM.

\section{References}

Barnes PM, et al. Complementary and alternative medicine use among adults: United States, 2002. Semin Integr Med. 2004; 2:54-71.

Benjamins MR. Religious influences on preventive health care use in a nationally representative sample of middle-age women. J Behav Med. 2006; 29:1-16. [PubMed: 16397821]

Brim, OG., et al. National Survey of Midlife Development in the United States [MIDUS], 1995-1996. DataStat, Inc.; Ann Arbor, MI: Boston: Harvard Medical School, Dept. of Health Care Policy: 2003. Machine-readable data file [MRDF] distributed by Interuniversity Consortium for Political and Social Research. Ann Arbor, MI:

Davis, JA., et al. The General Social Surveys: Cumulative Codebook, 1972-2008. National Opinion Research Center; Chicago: 2008. Machine-readable data file [MRDF] distributed by Interuniversity Consortium for Political and Social Research. Ann Arbor, MI:

Fuller, RC. Spiritual, but not religious: Understanding unchurched America. Oxford University Press; New York: 2001.

Hildreth KD, Elman C. Alternative worldviews and the utilization of conventional and complementary medicine. Sociol Inq. 2007; 77:76-103.

Honda K, Jacobson JS. Use of complementary and alternative medicine among United States adults: The influences of personality, coping strategies, and social support. Prev Med. 2005; 40:46-53. [PubMed: 15530580]

Kessler RC, et al. Long-term trends in the use of complementary and alternative medical therapies in the US. Ann Intern Med. 2001; 135:262-268. [PubMed: 11511141]

Levin JS, Coreil J. New age healing in the US. Soc Sci Med. 1986; 23:889-897. [PubMed: 3798167] 
Marler PL, Hadaway CK. "Being religious" or "being spiritual" in America: A zero-sum proposition? J Sci Stud Rel. 2002; 41:289-300.

McCurdy EA, et al. Religiosity is associated with the use of complementary medical therapies by pediatric oncology patients. J Pediat Hematol Onc. 2003; 25:125-129.

Newport, JP. The new age movement and the biblical worldview: Conflict and dialogue. Eerdmans; Grand Rapids, MI: 1998.

Ni H, Simile C, Hardy AM. Utilization of complementary and alternative medicine by United States adults. Med Care. 2002; 40:353-358. [PubMed: 12021691]

O'Mathuna, D.; Larimore, W. Alternative medicine: The Christian handbook. Eerdmans; Grand Rapids, MI: 2001.

Roof, WC. Spiritual marketplace. Princeton University Press; Princeton, NJ: 2000.

Royston P. Multiple imputation of missing values: update. Stata J. 2005; 5:188-201.

Shahabi L, et al. Correlates of self-perceptions of spirituality in American adults. Ann Behav Med. 2002; 24:59-68. [PubMed: 12008795]

Zhai JE, et al. Spiritual, but not religious: The influence of parental divorce on the religious and spiritual identities of young adults. Rev Relig Res. 2008; 49:359-374.

Zinnbauer BJ, et al. The emerging meanings of religiousness and spirituality: Problems and prospects. J Pers. 1999; 67:889-919. 
Table 1

Variable Overview and Descriptive Statistics

\begin{tabular}{|c|c|c|c|c|}
\hline Variable & Description & Range & $\begin{array}{l}\text { Proportion / } \\
\text { Mean* }\end{array}$ & $\begin{array}{l}\text { Std. } \\
\text { Dev. }\end{array}$ \\
\hline \multicolumn{5}{|l|}{ CAM Use } \\
\hline Alternative medical systems & $\begin{array}{l}\text { Acupuncture (stimulation of specific body / } \\
\text { pressure points) and homeopathy (small doses } \\
\text { of diluted preparations or substances) }\end{array}$ & $0-1$ & $03.0 \%$ & - \\
\hline Body-mind therapies & $\begin{array}{l}\text { Biofeedback (manipulation of physiological } \\
\text { functions), hypnosis (manipulation of mental } \\
\text { states), imagery techniques (positive } \\
\text { imagination), prayer (connection to a higher } \\
\text { power), meditation / relaxation (self-induced } \\
\text { mode of consciousness), and spiritual healing } \\
\text { (channeling healing energy) }\end{array}$ & $0-1$ & $31.5 \%$ & - \\
\hline $\begin{array}{l}\text { Body-mind therapies (besides prayer, } \\
\text { meditation, and spiritual healing) }\end{array}$ & Biofeedback, hypnosis, and imagery techniques & $0-1$ & $04.7 \%$ & - \\
\hline Biology-based therapies & $\begin{array}{l}\text { Herbal medicine (dietary supplements), high- } \\
\text { dose megavitamins (large amounts of vitamins), } \\
\text { and special diets (balanced nutrients) }\end{array}$ & $0-1$ & $15.3 \%$ & - \\
\hline Energy therapies & $\begin{array}{l}\text { Healing touch (use of hands to manipulate and } \\
\text { balance energy fields) }\end{array}$ & $0-1$ & $02.1 \%$ & - \\
\hline Manipulative / body-based therapies & $\begin{array}{l}\text { Massage therapies (manipulate muscles), } \\
\text { exercise / movement therapies (physical activity } \\
\text { to stimulate physical and emotional health), and } \\
\text { chiropractic (manipulation of mechanical / } \\
\text { musculoskeletal systems) }\end{array}$ & $0-1$ & $25.1 \%$ & - \\
\hline Spirituality / religiousness & Spiritual and religious identities & & & \\
\hline Spiritual but not religious & & $0-1$ & $16.3 \%$ & - \\
\hline Religious but not spiritual & & $0-1$ & $07.4 \%$ & - \\
\hline Both spiritual and religious & & $0-1$ & $58.5 \%$ & - \\
\hline Neither spiritual nor religious & & $0-1$ & $17.8 \%$ & - \\
\hline Religious or spiritual attendance & Frequency of attendance & $1-5$ & 2.788 & 1.345 \\
\hline Age & In years & $25-74$ & 47.058 & 13.161 \\
\hline Female & Sex & $0-1$ & $50.9 \%$ & - \\
\hline Education & In years & $1-12$ & 6.724 & 2.468 \\
\hline Married & Marital status & $0-1$ & $64.6 \%$ & - \\
\hline West Region & Region of residence & $0-1$ & $20.1 \%$ & - \\
\hline Depression & Depressive symptoms (sum of 7 items) & $0-7$ & 0.674 & 1.850 \\
\hline Generalized anxiety disorder & Anxious symptoms (sum of 10 items) & $0-10$ & 0.165 & 0.965 \\
\hline Panic disorder & Panic symptoms (sum of 6 items) & $0-6$ & 0.351 & 1.078 \\
\hline Neuroticism & Neurotic personality ( 4 items; $\alpha=.74$ ) & $1-4$ & 2.240 & 0.662 \\
\hline Agreeableness & Agreeable personality ( 5 items; $\mathrm{\alpha}=.80$ ) & $1-4$ & 3.480 & 0.489 \\
\hline Conscientiousness & Conscientious personality ( 4 items; $\alpha=.57$ ) & $1-4$ & 3.405 & 0.457 \\
\hline Extraversion & Extraverted personality ( 5 items; $\alpha=.78$ ) & $1-4$ & 3.198 & 0.571 \\
\hline Openness & Open personality ( 7 items; $\alpha=.77$ ) & $1-4$ & 3.042 & 0.522 \\
\hline Persistence & Persistence in goal striving ( 5 items; $\alpha=.77$ ) & $1-4$ & 3.238 & 0.551 \\
\hline Positive reappraisals & Secondary control (4 items; $\alpha=.78)$ & $1-4$ & 3.154 & 0.609 \\
\hline Support from friends & Emotional support from friends ( 4 items; $\alpha=.88$ ) & $1-4$ & 1.788 & 0.675 \\
\hline
\end{tabular}




\begin{tabular}{lllll}
\hline Variable & Description & Range & $\begin{array}{l}\text { Proportion / } \\
\text { Mean* }\end{array}$ & $\begin{array}{l}\text { Std. } \\
\text { Dev. }\end{array}$ \\
\hline Strain from partner & Stress from partner (4 items; $\mathrm{\alpha}=.81)$ & $1-4$ & 2.761 & 0.649 \\
Strain from other family members & Stress from other family (4 items; $\mathrm{\alpha}=.80)$ & $1-4$ & 2.873 & 0.617 \\
BMI & Body mass index & $9-64$ & 26.806 & 5.438 \\
Heart trouble & Ever had heart trouble & $0-1$ & $12.5 \%$ & - \\
Cancer & Ever had cancer & $0-1$ & $07.0 \%$ & - \\
Health insurance & Has health insurance & $0-1$ & $87.4 \%$ & - \\
\hline
\end{tabular}

$\mathrm{n}=3032$.

Proportions (labeled with \%) are provided for dichotomous variables, and means are shown for all others. Additional information on these variables can be found in Honda \& Jacobson (2005). Data come from the 1995-1996 National Survey of Midlife Development in the United States (MIDUS). 
Table 2

Associations Between Spirituality / Religiousness and CAM Use (Selected Odds Ratios)

\begin{tabular}{|c|c|c|c|c|}
\hline & \multicolumn{2}{|c|}{$\begin{array}{c}\text { Model 1: } \\
\text { Comparison of spiritual only individuals } \\
\text { with all others on different types of CAM } \\
\text { use }\end{array}$} & \multicolumn{2}{|c|}{$\begin{array}{c}\text { Model 2: } \\
\text { Comparison of spiritual and religious } \\
\text { individuals with all others on different } \\
\text { types of CAM use }\end{array}$} \\
\hline & Crude & Adjusted & Crude & Adjusted \\
\hline \multicolumn{5}{|l|}{ Body-Mind Therapie } \\
\hline Spiritual only & - & - & $0.77(0.61,0.99)$ & $0.70(0.54,0.91)$ \\
\hline Religious only & $0.36(0.23,0.56)$ & $0.37(0.23,0.57)$ & $0.28(0.19,0.42)$ & $0.26(0.17,0.38)$ \\
\hline Spiritual and religious & $1.28(1.01,1.63)$ & $1.43(1.09,1.86)$ & - & - \\
\hline Neither spiritual nor religious & $0.22(0.15,0.33)$ & $0.28(0.19,0.43)$ & $0.17(0.12,0.25)$ & $0.20(0.14,0.29)$ \\
\hline \multicolumn{5}{|c|}{ Body-Mind Therapies (Besides Prayer, Meditation, and Spiritual Healing) } \\
\hline Spiritual only & - & - & $2.25(1.49,3.40)$ & $1.79(1.12,2.83)$ \\
\hline Religious only & $0.37(0.15,0.94)$ & $0.49(0.18,1.30)$ & $0.84(0.34,2.07)$ & $0.87(0.34,2.26)$ \\
\hline Spiritual and religious & $0.44(0.29,0.67)$ & $0.56(0.35,0.89)$ & - & - \\
\hline Neither spiritual nor religious & $0.22(0.10,0.46)$ & $0.33(0.14,0.75)$ & $0.49(0.24,1.02)$ & $0.58(0.24,1.36)$ \\
\hline \multicolumn{5}{|l|}{ Biologically-Based Therapies } \\
\hline Spiritual only & - & - & $0.91(0.69,1.23)$ & $0.90(0.66,1.24)$ \\
\hline Religious only & $0.53(0.32,0.88)$ & $0.61(0.35,1.07)$ & $0.49(0.31,0.77)$ & $0.56(0.34,0.92)$ \\
\hline Spiritual and religious & $1.09(0.81,1.46)$ & $1.11(0.80,1.51)$ & - & - \\
\hline Neither spiritual nor religious & $0.45(0.29,0.71)$ & $0.68(0.42,1.08)$ & $0.42(0.28,0.61)$ & $0.61(0.40,0.93)$ \\
\hline \multicolumn{5}{|l|}{$\underline{\text { Alternative Medical Systems }}$} \\
\hline Spiritual only & - & - & $1.66(0.99,2.81)$ & $1.39(0.77,2.51)$ \\
\hline Religious only & $0.07(0.01,0.55)$ & $0.11(0.01,0.85)$ & $0.12(0.02,0.90)$ & $0.15(0.02,1.14)$ \\
\hline Spiritual and religious & $0.60(0.36,1.01)$ & $0.72(0.40,1.29)$ & - & - \\
\hline Neither spiritual nor religious & $0.15(0.05,0.49)$ & $0.25(0.07,0.87)$ & $0.25(0.08,0.78)$ & $0.35(0.10,1.17)$ \\
\hline \multicolumn{5}{|l|}{ Energy Therapies } \\
\hline Spiritual only & - & - & $6.47(4.84,8.66)$ & $6.91(4.59,19.40)$ \\
\hline Religious only & $0.28(0.17,0.46)$ & $0.35(0.18,0.67)$ & $1.79(1.08,2.97)$ & $2.38(1.27,4.48)$ \\
\hline Spiritual and religious & $0.15(0.12,0.21)$ & $0.14(0.10,0.22)$ & - & - \\
\hline Neither spiritual nor religious & $0.58(0.42,0.79)$ & $0.48(0.32,0.73)$ & $3.74(2.78,5.03)$ & $3.32(2.23,4.94)$ \\
\hline \multicolumn{5}{|l|}{ Manipulative Body-Based } \\
\hline Spiritual only & - & - & $1.04(0.81,1.34)$ & $1.12(0.86,1.47)$ \\
\hline Religious only & $0.91(0.61,1.37)$ & $0.91(0.59,1.39)$ & $0.95(0.66,1.37)$ & $1.02(0.69,1.49)$ \\
\hline Spiritual and religious & $0.96(0.75,1.23)$ & $0.89(0.68,1.16)$ & - & - \\
\hline Neither spiritual nor religious & $0.63(0.45,0.88)$ & $0.74(0.52,1.06)$ & $0.66(0.50,0.87)$ & $0.83(0.62,1.13)$ \\
\hline
\end{tabular}

$\mathrm{n}=3032$. Cell entries are selected odds ratios (95\% confidence intervals in parentheses) from logistic regression models. Cells containing a "-" are reference categories, and bold denotes significant relationships $(\mathrm{p}<0.05)$. Crude estimates are unadjusted odds ratios, and adjusted estimates include controls for respondent's frequency of attendance at religious services, age, sex, race, education, marital status, region of residence, depression, generalized anxiety disorder, panic disorder, Big Five personality traits (neuroticism, agreeableness, conscientiousness, openness, and extraversion), persistence, positive reappraisals, support and strain from both partners and friends, BMI, heart trouble, cancer, and health insurance status. Additional information on these variables, as well as all covariates, can be found in Honda \& Jacobson (2005). Data come from the 1995-1996 National Survey of Midlife Development in the United States (MIDUS). 